\title{
URINARY CLUSTERIN CONCENTRATIONS - A POSSIBLE MARKER OF NEPHROPATHY? PILOT STUDY.
}

\author{
Pavlina Solichova $^{\mathrm{a} * \mathrm{~d}}$, Michal Karpisek ${ }^{\mathrm{b}}$, Radka Ochmanova ${ }^{\mathrm{a}}$, Zuzana Hanulovac, \\ Viera Humenanska ${ }^{\mathrm{c}}$, David Stejskal ${ }^{\mathrm{a}, \mathrm{d}}$, Josef Bartek ${ }^{\mathrm{d}}$
}

\author{
${ }^{a *}$ Department of Laboratory Medicine and Department of Internal Medicine, Hospital Sternberk branch office Central \\ Moravia Hospital Company, Czech Republic \\ ${ }^{b}$ Institute of human pharmacology and toxicology, Faculty of Pharmaceutical Sciences, Veterinary and Pharmaceutical \\ University Brno, Czech Republic \\ c Gnosis Bratislava, Slovakia \\ d Institute of Medical Chemistry and Biochemistry, Faculty of Medicine and Dentistry, Palacky University Olomouc, Czech \\ Republic \\ e-mail: solichova.pavlina@seznam.cz
}

Received: September 2, 2007; Accepted: October 17, 2007

Key words: Clusterin/Urine/Tubulopathy/Nephropathy/Renal function/Proteinuria

Background: Clusterin is a glycoprotein which participates in a number of pathophysiological processes in the organism. Information about clusterin use in the diagnosis of nephropathy and the differential diagnosis of proteinuria has been published recently.

Aim: Search for correlations between urinary clusterin concentration and other renal function markers. Evaluation of urinary clusterin measurement use in the differential diagnosis of nephropathy.

Methods: Urea, creatinine, IgG, transferin, $\mathrm{Na}, \mathrm{K}$ in serum and 24-hour collected urine were measured in a sample of 82 individuals. Cystatin C in sera was also measured as were GMT, $\alpha-1$ microglobulin, albumin, total protein in urine. In all probands urinary clusterin was assayed (ELISA).

Results: Urinary clusterin values correlated with urinary total protein concentrations $(r=0.28 ; p=0.018)$, total protein/creatinine index $(r=0.26 ; p=0.02)$. No correlation was found between urine clusterin concentration and glomerular filtration rate, age, urine GMT/creatinine, $\alpha$-1-microglobulin, urine albumin and albumin/creatinine ratio or $\mathrm{Na}, \mathrm{K}$ fractional excretions. We found no urinary clusterin differences by sex of probands.

No evidence of any relationship between urine clusterin and presence of defect of renal function, number of risk factors $\left(\chi^{2}=16.0 ; \mathrm{DF}=15 ; \mathrm{p}=0.38\right)$, albumin/creatinine index $\left(\chi^{2}=0.76 ; \mathrm{DF}=3 ; \mathrm{p}=0,86\right)$, total protein/creatinine $\left(\chi^{2}=6.5 ; \mathrm{DF}=3 ; \mathrm{p}=0.09\right), \mathrm{GMT} /$ creatinine $\left(\chi^{2}=2.3 ; \mathrm{DF}=3 ; \mathrm{p}=0.51\right)$, high urinary $\alpha-1$-microglobulin $\left(\chi^{2}=4.1\right.$; $\mathrm{DF}=3 ; \mathrm{p}=0.25)$ or decreased of GFR $\left(\chi^{2}=1.3 ; \mathrm{DF}=3 ; \mathrm{p}=0.74\right)$.

Conclusions: A positive correlation exists between urinary clusterin and urinary total protein and total protein/ creatinine index. Urinary clusterin measurement with ELISA test does not offer any advantage over routinely used parameters for nephropathy diagnosis and the differential diagnosis of proteinuria type.

\section{INTRODUCTION}

The differential diagnosis of proteinuria is an essential component in the diagnosis of renal diseases. Proteinuria may be caused by increased capillary permeability to proteins, with excess tubule capacity for back resorption (glomerular proteinuria), disorders in back resorption of filtrated proteins (tubular proteinuria), extreme increase in some blood proteins (prerenal proteinuria) or inflammatory and cytolytic processes in the urinary tract (postrenal proteinuria). The diagnostic examination of proteinuria is made by determining the urinary protein/creatinine index, urine electrophoresis, measurement of albumin and urinary albumin/creatinine index, calculation of selectivity proteinuria index, determination of $\alpha$-1-microglobulin, light chain immunoglobulins and urinary paraproteins.

Recent information suggests the possible importance of other potential diagnostic urinary parameters.
A number of papers have been published on the possible use of urinary clusterin concentration analysis in the assessment of type proteinuria and renal function disor$\operatorname{ders}^{5-6}$.

\section{METHODS}

The study tested 82 individuals after obtaining their informed consent. The probands had suspect nephropathy of various etiology (49 persons with suspect early diabetic nephropathy, 5 individuals with primary glomerulopathy, 28 subjects with nephropathy due to chronic pyelonephritis).

To evaluate the presence and severity of nephropathy, the following scheme of minimally three risk parameters was used: a) decreased GF value according to MDRD (Modification of Diet in Renal Disease) $^{7}<1.1 \mathrm{ml} / \mathrm{s}, \mathrm{b}$ ) 
Table 1. Basic statistical parameters (normality evaluated with Komolgorov-Smirnov test)

\begin{tabular}{|c|c|c|c|c|c|}
\hline Parameter & Units & Mean & Median & SD & Normality \\
\hline BMI & - & 28.5 & 28.0 & 7.1 & No \\
\hline U-Protein & $\mathrm{g} /$ day & 0.62 & 0.25 & 0.95 & No \\
\hline U-Protein/U-Creatinine & $\mathrm{g} / \mathrm{mmol}$ & 97.6 & 36.5 & 153.5 & No \\
\hline U-Clusterin & $\mathrm{kIU} / 1$ & 79.2 & 50.0 & 135.6 & No \\
\hline FE K & $\%$ & 12.2 & 9.5 & 11.2 & No \\
\hline FE Na & $\%$ & 1.4 & 1.2 & 0.99 & No \\
\hline U-Creatinine & $\mathrm{mmol} /$ day & 12.7 & 11.5 & 7.8 & No \\
\hline GFR Cystatin C & $\mathrm{ml} / \mathrm{s}$ & 1.4 & 1.2 & 0.8 & No \\
\hline U-GMT/U-Creatinine & nkat/mmol & 82.5 & 74.2 & 45.4 & No \\
\hline Selectivity proteinuria index & - & 0.41 & 0.34 & 0.22 & No \\
\hline GFR MDRD & $\mathrm{ml} / \mathrm{s}$ & 1.1 & 1.0 & 0.4 & No \\
\hline Number of risk factors & - & 3.1 & 3.0 & 1.2 & No \\
\hline S-Cystatin C & $\mathrm{mg} / 1$ & 1.22 & 1.1 & 0.5 & No \\
\hline S-Creatinine & umol/1 & 118.8 & 110.0 & 55.2 & No \\
\hline S-Transferin & $\mathrm{g} / 1$ & 2.1 & 2.2 & 0.6 & Yes \\
\hline S-Immunoglobulin G & $\mathrm{g} / 1$ & 9.9 & 10.1 & 2.8 & Yes \\
\hline U-Albumin & $\mathrm{mg} /$ day & 297.8 & 81.6 & 619.5 & No \\
\hline U-a-1-microglobulin & $\mathrm{mg} /$ day & 18.5 & 10.6 & 27.2 & No \\
\hline U-Albumin/U-Creatinine & $\mathrm{mg} / \mathrm{mmol}$ & 49.0 & 10.7 & 94.8 & No \\
\hline U-GMT & nkat/1 & 0.6 & 0.5 & 0.5 & No \\
\hline U-IgG & $\mathrm{mg} / \mathrm{l}$ & 0.05 & 0.01 & 0.11 & No \\
\hline U-Transferin & $\mathrm{mg} / 1$ & 0.01 & 0.01 & 0.01 & No \\
\hline Age & years & 66.3 & 68.0 & 16.0 & No \\
\hline
\end{tabular}

SD - standard deviation.

Table 2. Quartiles of urine clusterin and presence of nefropathy

\begin{tabular}{|l|c|c|c|c|c|}
\hline Presence of defect & Quartile 1 & Quartile 2 & Quartile 3 & Quartile 4 & Suma \% \\
\hline Defekt No & 15 & 6 & 0 & 0 & 25.9 \\
\hline Defekt Yes & 38 & 18 & 2 & 2 & 74.1 \\
\hline Suma \% & 65.4 & 29.6 & 2.5 & 2.5 & 100.0 \\
\hline
\end{tabular}

$\chi^{2}=1.6 ; \mathrm{DF}=3 ; \mathrm{p}=0.67$

enhanced urinary albumin/creatinine index $>2.5 \mathrm{~g} / \mathrm{mol}$ in men and $>3.5 \mathrm{~g} / \mathrm{mol}$ in women, c) enhanced urinary $\alpha$-1-microglobulin $>10 \mathrm{mg} / \mathrm{l}, \mathrm{d}$ ) enhanced urinary GMT/ creatinine $>94.6 \mathrm{nkat} / \mathrm{mmol}, \mathrm{c})$ enhanced urinary protein/creatinine $>20 \mathrm{~g} / \mathrm{mol}$.

The probands did not need to observe any special diet before sample collection. Laboratory parameters were determined in samples of venous blood and urine collected for 24 hours. Biologic material samples were centrifuged within $60 \mathrm{~min}$ after collection $\left(10 \mathrm{~min}\right.$ at $2000 \mathrm{~g}$ and $4^{\circ}$ $\mathrm{C}$ ), then analyzed and kept at $-80^{\circ} \mathrm{C}$ for at least 10 days. In blood and urine we determined urea (Advia 1650), creatinine (Jaffe, Advia 1650), IgG (Advia 1650), transferin (Advia 1650), Na and K (Advia 1650), serum cystatin C
(Advia 1650). Only in urine were measured GMT (Advia 1650), $\alpha$-1-microglobulin (Advia 1650), albumin (Advia 1650 ), total protein (Advia 1650). In all probands urinary clusterin was assayed by the ELISA method (BioVendor Laboratory Medicine, Czech Republic; limit of detection $50 \mathrm{kU} / 1$, repeatability in three levels in 8 replicates $<6 \%$, intermediate precision $<9 \%$, urine stability without preservative agents at $-20{ }^{\circ} \mathrm{C}$ for at least one month). In addition a selectivity proteinuria index was calculated ${ }^{8}$ and glomerular filtration rate was assessed from serum cystatin $\mathrm{C}^{8}$.

To compare the studied parameters, the group of probands was divided according to clusterin assessment into quartiles. The presence of other measured risk pa- 


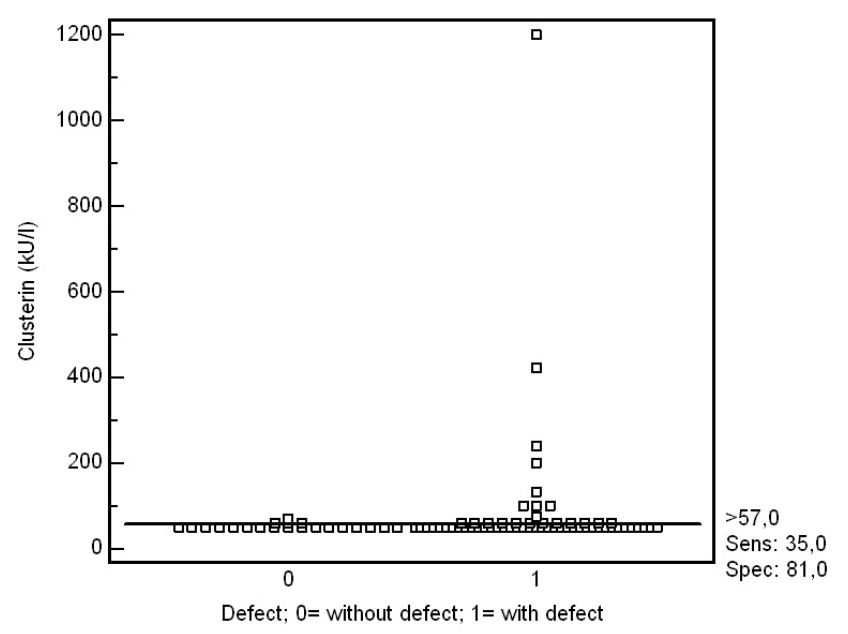

Fig. 1. Interactive dot diagram for evaluation of the diagnostic efficacy of urine clusterin measurement

rameters were also calculated as their overall number and then statistically processed.

The data were processed statistically by means of the MedCalc program (Belgium). Values of individual parameters were expressed as means \pm standard deviation and medians. Correlations of individual parameters were studied using a Spearman correlation coefficient (by data distribution). A value of $p<0.05$ was considered statistically significant. The data were evaluated for correlations between clusterin levels (measurable vs. non-measurable) and other studied parameters (over $v s$. below a limit of detection) and using a chi-squared test $\left(\chi^{2}\right.$ - test).

\section{RESULTS}

Most data showed an abnormal distribution. Only 28 probands (34\%) had higher clusterin values than the limit of detection (50 kU/1) (Tab 1).

Urinary clusterin values correlated with urinary total protein concentrations $(\mathrm{r}=0.28 ; \mathrm{p}=0.018)$, total protein/creatinine index $(\mathrm{r}=0.26 ; \mathrm{p}=0.02)$. No correlation was found between urine clusterin concentration and glomerular filtration rate, age, urine GMT/creatinine, $\alpha$ 1-microglobulin, urine albumin and albumin/creatinine ratio or $\mathrm{Na}, \mathrm{K}$ fractional excretions. We found no urinary clusterin differences by sex of probands.

Using a $\chi^{2}$-test there was no clear evidence of relationship between urine clusterin and presence of defect of renal function (see above) (Tab 2), number of risk factors $\left(\chi^{2}=16.0 ; \mathrm{DF}=15 ; \mathrm{p}=0.38\right)$, albumin/creatinine index $\left(\chi^{2}=0.76 ; \mathrm{DF}=3 ; \mathrm{p}=0.86\right)$, total protein/ creatinine $\left(\chi^{2}=6.5 ; \mathrm{DF}=3 ; \mathrm{p}=0.09\right)$, GMT/creatinine $\left(\chi^{2}=2.3 ; \mathrm{DF}=3 ; \mathrm{p}=0.51\right)$, high urinary $\alpha-1$-microglobulin $\left(\chi^{2}=4.1 ; \mathrm{DF}=3 ; \mathrm{p}=0.25\right)$ or decreased of GFR $\left(\chi^{2}=1.3 ; \mathrm{DF}=3 ; \mathrm{p}=0.74\right)$.

The division of patients according to severity of renal dysfunction showed diagnostic insufficient diagnostic ef- ficacy of urine clusterin (AUC 0.55; $95 \%$ CI 0.44-0.66; LR +1.8 , sensitivity of clusterin $35 \%$ and specificity $81 \%$ ) (Fig 1).

\section{DISCUSSION}

Clusterin (70-80 kDa; synonym ApoJ) is a glycoprotein involved in many physiological and pathophysiological processes. Two clusterin forms exist: the first (secretory, exogenous) occurs in biological fluids; the second form (endogenous) is contained in the cytoplasm and nucleus ${ }^{4}$. Secretory clusterin originates from preclusterin $(60 \mathrm{kDa})$, which is subsequently cleaved into two chains of mature protein (alpha, beta). This form has antiapoptotic and antiangiogenetic effects ${ }^{2-4}$. Endogenous clusterin originates by alternative cleaving of preclusterin; the final molecule acts as a strong stimulator of apoptosis ${ }^{4}$.

Clusterin effects can be summarized as follows: secretory clusterin acts as a cytoprotective extracellular chaperon and its expression and synthesis are increased in individuals suffering from various froms of stress and especially in patients with malignant tumors ${ }^{1-4}$.

Extracellular clusterin plays a number of roles, e.g. in the production of amyloid in Alzheimer's disease, binding abnormal prions, "heat shock proteins" and reduced degradation of many components of the extracellular matrix. Clusterin is also involved in immune processess regulation, lipid transport, sperm maturation and protection of cell membranes ${ }^{4}$.

The results of experimental studies indicate the pathophysiologic importance of clusterin particularly in the pathogenesis of glomerulonephritis, polycystic kidneys, renal tubular diseases, neurodegenerative disorders, atherosclerosis, myocardial infarction and malignant tumors ${ }^{4}$.

As the data are still sporadic and often contradictory, the aim of the present pilot study was to determine relations between urinary clusterin concentration and other parameters of renal functions in urine, as well as assess the use of clusterin measurement in the differential diagnosis of proteinuria.

With regard to the presence and diagnostic importance of urinary clusterin there is ambiguity and numerous discrepancies. Several years ago, the potential importance of serum clusterin was written in the diagnosis of renal disorders; many patients with renal disorders had lower urinary clusterin, which was considered as one cause of renal diseases (e.g. clusterin deficiency leads to activation of complement cascade and thus to possible renal injury $)^{5-11}$. On the other hand, there is experimental evidence that individuals with impaired renal parenchyma or toxic injury have higher urinary clusterin concentrations (together with other proteins $)^{6,10,12}$. This is interesting apropos clusterin production by a stressed cell; enhanced urinary clusterin levels could be permanent and independent of diuresis changes or renal perfusion ${ }^{4,6}$.

Our findings confirme significant correlations between urinary clusterin and total protein and total protein/creatinine index, but no unambiguous proof was found for 
correlations of measured clusterin values with enhanced parameters in urine. We also failed to confirm the assumption that clusterin determination more significantly correlated with tubular proteinuria than glomerular proteinuria. It should be mentioned here that clusterin in the organism is enhanced nonspecifically under extreme cell stress. These reasons could be limiting for the generalized diagnostic effectiveness of urinary clusterin in the diagnosis of nephropathy.

It can be concluded that despite the proved existence of a positive correlation between urinary clusterin and urinary total protein, urinary clusterin measurement does not confirm any evident advantage to routinely used parameters for nephropathy diagnosis and the differential diagnosis of proteinuria type.

\section{REFERENCES}

1. Kruger S, Mahnken A, Kausch I, Feller AC. Value of clusterin immunoreactivity as a predictive factor in muscle-invasive urothelial bladder carcinoma. Urology 2006; 67: 105-9.

2. Kim BM, Kim SY, Lee S, Shin YJ, Min BH, Bendayan M, et al. Clusterin induces differentiation of pancreatic duct cells into insulin-secreting cells. Diabetologia 2006; 49:311-20.
3. Gleave ME, Gleave J, Burt HM. The inhibition of angiogenesis by antisense oligonucleotides to clusterin. Angiogenesis 2005; 8:229-8.

4. Silkensen J. Clusterin: physiologic and pathophysiologic considerations. Int J Biochem Cell Biol 2005; 27:633-45.

5. Bruschi M, Candiano G, Rastaldi MP, Scolari F, Passerini P, Musante L, et al. Depletion of clusterin in renal diseases causing nephrotic syndrome. Kidney Int 2002; 62:2184-94.

6. Hidaka S, Kranzlin B, Gretz N, Witzgall R. Urinary clusterin levels in the rat correlate with the severity of tubular damage and may help to differentiate between glomerular and tubular injuries. Cell. Tissue Res 2002; 310:289-96.

7. Jabor A, Hornová L, Bořil P, Moravcová H, Fischlová D. Rovnice MDRD: pro a proti. Klin Biochem Metab 2005; 13:172-6.

8. Masopust J. Klinická biochemie, požadování a hodnocení biochemických vyšetření. Olympus; 1998.

9. Grubb A, Björk J, Lindström V, Sterner G, Bondesson P, Nyman U. A cystatin C-based formula without anthropometric variables estimates glomerular filtration rate better than creatinine clearance using the Cockcroft-Gault formula. Scand J Clin Lab Invest 2005; 65:153-62.

10. Eti S, Cheng CY, Marshall A, Reidenberg MM. Urinary clusterin in chronic nephrotoxicity in the rat. Proc Soc Exp Biol Med 1993; 202:487-490.

11. Saunders JR, Aminian A, McRae JL, O'Farrell KA, Adam WR, Murphy BF. Clusterin depletion enhances immune glomerular injury in the isolated perfused kidney. Kidney Int 1994; 45:817-27.

12. Ishii A, Sakai Y, Nakamura A. Molecular pathological evaluation of clusterin in rat model of unilateral ureteral obstruction as a possible biomarker of nephrotoxicity. Toxicil Pathol. 2007; 35:376-82. 